\title{
Antalya ili turizminin gelişimini ve etkilerini yerel halk nasıl değerlendirmektedir?
}

\author{
How do the local people evaluate the development and the effects of tourism in Antalya province? \\ İsmail Kervankıran*a Erkan Bulut ${ }^{\mathrm{a}}$ \\ a Süleyman Demirel Üniversitesi, Fen-Edebiyat Fakültesi, Coğrafya Bölümü, Isparta.
}

\begin{tabular}{|c|c|}
\hline MAKALE BILGi & ÖZ / ABSTRACT \\
\hline Geliş/Received: 29.06.2015 & Sahip olduğu denizi, iklimi, tarihi ve kültürel değerleri bakımından Türkiye'nin en önemli turistik \\
\hline Kabul/Accepted: 15.09.2015 & çekim merkezlerinden biri olan Antalya ilinde yerli ve yabancı turist talebi sürekli artmaktadır. Bu \\
\hline Anahtar Kelimeler: & $\begin{array}{l}\text { çallşmada, Antalya merkez Ilçelerınde yaşayan yere nalkın turızmın etkılerıne yonelık algıllarının } \\
\text { belirlenmesi amaçlanmıştır. Araştırmanın evrenini Antalya ili merkez ilçelerinde (Konyaaltı, Murat- }\end{array}$ \\
\hline Turizm & paşa, Kepez, Aksu ve Döşemealt) yaşayan yerel halk oluşturmaktadır. Bu amaçla beş ilçede toplam \\
\hline Antalya & 464 kişiye uygulanan anketin istatistiksel analizlere uygun olduğu görülmüştür. Analizler bilgisayar \\
\hline Yerel Halk & ortamında ve SPSS 20.00 programı yardımıyla ve 0.05 anlamlııı düzeyinde test edilmiştir. Elde edi- \\
\hline Sürdürülebilirlik & $\begin{array}{l}\text { len verilerin analizi, frekans analizleri, Mann-Whitney U testi ve Kruskall-Wallis analizleri ile ger- } \\
\text { çekleştirilmiştir. Analiz sonuçlarına bakılarak; yerel halkın turist profiline yönelik beklentilerinin }\end{array}$ \\
\hline Keywords: & nitelikli turist gelmesi yönünde olduğu, Antalya'da kontrolsüz turizm büyümesinin çevresel sorun- \\
\hline Tourism & lara neden olduğu, turizm faaliyetlerinin halkın yaşam standartlarını artırdığı, mevcut turizm poli- \\
\hline $\begin{array}{l}\text { Antalya } \\
\text { Local people }\end{array}$ & tikalarının doğal kaynakların sürdürebilirliğini destekler nitelikte olmadığı sonucu ortaya çıkmıştır. \\
\hline $\begin{array}{l}\text { Local people } \\
\text { Sustainability }\end{array}$ & National and international tourism demands are constantly increasing in the province of Antalya \\
\hline & which is among the most important tourist attraction centers of Turkey with regard to its sea, cli- \\
\hline $\begin{array}{l}\text { *Sorumlu yazar/Corresponding author } \\
\text { (i. Kervankıran) } \\
\text { ikervankiran03@gmail.com }\end{array}$ & $\begin{array}{l}\text { pacts of tourism in the central districts of Antalya. The local people living in the central districts of } \\
\text { Antalya (Konyaalt, Muratpaşa, Kepez, Aksu and Dösemealt) constitute the population of the study. } \\
\text { In the study first a survey was conducted of } 464 \text { people in these five districts, and then the answers } \\
\text { of the respondents were analyzed by SPSS } 20.00 \text { with } 0.05 \text { significance level. Frequency analysis, }\end{array}$ \\
\hline http://dx.doi.org/10.17211/tcd.29902 & $\begin{array}{l}\text { Mann-Whitney } U \text { test, and Kruskall-Wallis analysis were carried out to evaluate the results. As the } \\
\text { results of the analysis revealed, the expectations of local people from tourist profile are towards } \\
\text { having qualified tourists, the uncontrolled tourism developments cause environmental problems, } \\
\text { tourism activities increase the living standards of the society, and the current tourism policies do } \\
\text { not support the sustainability of natural resources in the province of Antalya. }\end{array}$ \\
\hline
\end{tabular}

\section{Giriş}

Yeni istihdam olanakları, gelir, ek gelir vergisi, döviz girdisine kaynak oluşturan turizm gelişimi, aynı zamanda toplumun alt yapısını güçlendirir, diğer ekonomileri etkiler (Ko ve Stewart, 2002). Bundan dolayı turizm, tüm dünyada ekonomik gelişim programlarının en önemli bölümlerinden birini oluşturmaktadır ve turizm gelişimi, bu programlarda yerel ekonomileri güçlendirmeye yönelik gerçekleştirilen ekonomik faaliyetler olarak ortaya çıkmaktadır (Harrill, 2004). Bununla birlikte bir bölgede turizmin gelişimi ekonomik ve sosyal olarak çok iyi imkânlar sağlıyor olsa da, aynı gelişimin çevresel değerler üzerinde güçlü bir baskısının olduğu da bir gerçektir (Bestard ve Nadal, 2007). Bu nedenle; hem doğal hem de beşeri kaynakların daha uzun süre devamlılığını sağlayan, sayısı artan turistlerin memnuniyet seviyesini de koruyan, sürekli bir kontrol mekanizmasının denetiminde turist ve ev sahibi bölgelerin mevcut gereksinimini karşılarken gelecek için de koruma ve firsatların oluşturulma- sına imkân veren (Inskeep, 1991) sürdürülebilir turizm yaklaşımı, son yıllarda turizm planlamalarında daha fazla yer almaya başlamıştır.

Turizm gelişiminin sürdürülebilir olmasını sağlamak turistik destinasyonların gelişimi sürecinde toplumdaki her bireyin katılımı ile gerçekleşmektedir (Dyer vd., 2007). Çünkü turizm gelişimi ile birlikte birçok paydaş olumlu ya da olumsuz olarak etkilenmekte olup (Gunn, 1988; Mansuroğlu, 2006; Nicholas, vd., 2009; Pitons, 2009; Kozak, 2014) bu süreçten en fazla etkilenen paydaş ise yerel halktır (Swarbrooke, 1999; Yoon, 2002; Sekhar, 2003; Byrd vd. 2009). Bir turizm planının başarısı, yerel toplumun desteği olmadan gerçekleşemez. Yerel halk, turisti kabul ettiği ölçüde turist, bulunduğu mekândan memnuniyet hissedecektir (Gürsoy ve Rutherford, 2004). Yerel halkı turizm gelişim sürecine dâhil etmek, bu konudaki görüş ve önerilerini almak ve gelecekteki turizm gelişmesini teşvik yönünde karşı- 
Iıklı fikir alışverişi yapmak, yerel halkın karar merkezlerini etkileyebilmesi ve kendilerini turizmin bir parçası olarak hissetmeleri açısından oldukça önemlidir. Eğer turizmin sürdürülebilir kılınması isteniyorsa planlanan turizmin, gelişme şekli, ölçeği ve konumu ile ilgili olarak yöre toplumunun kabulünü kazanması gerekmektedir (Avcıkurt, 2003). Inskeep'e (1991) göre, turizm planlamasının toplum düzeyinde gerçekleşmesi turizmin sürdürülebilirliği açısından önem taşımaktadır. Dolayısıyla planlama süreci, toplumun mevcut kültürel, tarihsel ve çevresel birikimlerini, zenginliğini koruyan ve sürdürülebilir kılan; turizm gelişiminin olumsuz etkilerini en düşük seviyelere indirgeyen; toplumsal değerlere duyarlılık prensiplerine uygun bir şekilde yürütülmelidir. Doğru planlama olmadan yürütülen gelişim stratejilerinin geri dönüşü, toplum açısından sağlıksız bir gelişim ve toplumsal hedeflerden sapmalar şeklinde olmaktadır (Inskeep, 1991).

Yerel halkın turizm gelişimine verdiği desteğin anlaşılması, yerel hükümetler, politika üretenler ve işverenler açısından önem taşımaktadır. Yerel halkın aktif desteğinin alınması gelişimin başarılı ve sürdürülebilir olmasını sağlamaktadır. Tam tersi bir durumun ortaya çıkması gelişimi engelleyebilir ya da tamamen durdurabilir. Yerel halkın yeni yatırımlara ihtiyaç duyması, ortaya çıkacak faydalar konusunda daha olumlu düşünmelerini ve olumsuz etkileri göz ardı etmelerini sağlamaktadır (Gürsoy ve Rutherford, 2004). Bunun için turizm gelişimi ile ortaya çıkan tehditleri en aza indirmek ve koruma yaklaşımını geliştirmek için çeşitli paydaşlar arasında iletişim ve işbirliğine intiyaç vardır (Besculides vd., 2002). Çünkü paydaşlar arası iletişimin ve işbirliğinin sağlanması, turizme yönelik desteğin artmasına ve turizm konusunda olumlu kararların alınmasına neden olmaktadır.

Bir bölgedeki turizm gelişimi yerel halkın yaşam kalitesini artırmaya yönelik olmalıdır (Latkova, 2008). Bunun gerçekleşmesi için de turizmin ekonomik, sosyo-kültürel ve çevresel etkilerini yerel halkın faydasına çevirmek gerekmektedir. Çünkü, yerel halk kendi ekonomik, sosyal ve psikolojik intiyaçlarını karşılamak amacıyla turizm gelişimini önemsemektedir (Ap, 1992). Toplumun yapısı, turistlerin alanda kalış süreleri ve turizme ekonomik bağımlılık gibi bazı sosyal ve kültürel faktörler yerel halkın turizme karşı tutumunu etkilemektedir. Turizme ekonomik olarak bağımlılık, yerel halkın turizmi kabullenme seviyesini artrrmaktadır (Besculides vd., 2002). Doğru planlanmayan, turistlerin ve toplumun istek ve beklentilerinin ihmal edildiği, gerekli önlemlerin alınmadığı, doğal peyzajı bozan ve yerel değerlere önem vermeyen turizm gelişimi, belki başlangıçta karşılıklı çıkar ilişkisinden dolayı yerel halk tarafindan olumlu karşılanacak, ancak ilerleyen süreçlerde turizmin olumsuz etkileri ile karşılaşınca yerel halkın tepkisine neden olacaktır.

Bunun için turizmin gelişmeye başladığı mekânlarda turizmin olumsuz etkileri ortaya çıkmadan, yerel halkın turizmin etkilerine ve turizmden kaynaklanan problemlere yönelik algılarının ve tutumlarının araştırılması o bölgedeki turizmin sürdürülebilirliği açısından çok önemlidir. Yerel halkın, turizm planlaması ve gelişmesine yönelik algılarını, tutumlarını ve tepkilerini ölçmek amacıyla birçok yerli ve yabancı araştırmacı tarafindan çaIışmalar yapılmıştır (Ap, 1992; Jurowski vd. 1997; Emekli, 2001; Teye vd. 2002; Yoon vd. 2001; Soykan, 2004). Gerçekleştirilen bu çalışmalarda turizm gelişiminin faydaları, turizm gelişiminin etkileri, yerel halkın turizme yönelik algısı, desteği, beklentileri ve çekinceleri incelenmiştir (Varnacı Uzun ve Somuncu 2011,
Baykan, 2007; Andereck, vd., 2005; Kervankıran, 2013; Güneş 2014).

Uygun coğrafi özellikleri, zengin doğal ve kültürel çekicilikleri, turistlere sunulan farklı turizm çeşitliliği, gelişmiş ulaşım sistemleri ve nitelikli turistik tesisleri ile Antalya ili, yerli ve özellikle yabancı turistler tarafindan her geçen gün daha fazla tercih edilmektedir. 1990 yılında konaklayan yabancı turistlerin $\% 16,6$ 'sı, yerli turistlerin \%5,2'si Antalya ilini tercih ederken, 2013 yılında bu oran yabancı turistlerde \%51,1'e, yerli turistlerde ise \%17,3'e yükselmiştir (Tablo 3).

Dünyada turizmin geliştiği mekanlarda; deniz kıyılarında kirlenme, ormanlık alanların tahrip edilmesi, doğal peyzajın bozulması, kontrolsüz ve plansız yapılaşma, verimli arazilerin üzerine turizm tesislerinin kurulması, sıvı ve kat atklarla artan su ve toprak kirliliği, doğal ortama ve yerel mimariye uygun olmayan betonlaşma gibi olumsuz çevresel etkilerin yanında, aşırı kalabalıklaşma, kültürün yozlaşması, yerel halkın memnuniyetsizliği, kültürel çatışma, dini ve ahlaki dönüşümler, suç oranında artış, yabancı düşmanlığı gibi bazı sosyal-kültürel olumsuz etkiler de artmaktadır. Çalışma alanında da son yıllarda turizmin hızlı gelişimi ile birlikte, buna benzer baskıların ve değişimlerin yaşanmaya başladığı görülmektedir. Kuşkusuz bu baskı ve değişimden en fazla etkilenen ise Antalya'da yaşayan yerel halktır. Turizmin geliştiği bölgelerde yerel halkın bu değişime ve gelişime olan bakış açılarının araştırılması, bu konudaki endişelerinin tespit edilmesi ve bu doğrultuda gerekli tedbirlerin alınması, o bölgedeki turizmin sürdürülebilirliği ve sağlıklı gelişimi açısından büyük önem taşımaktadır. Bundan dolayı bu çalışmada, Türkiye'de turizmin en hızlı gelişme gösterdiği Antalya ilinde yaşayan yerel halkın, turizmin gelişimine olan yaklaşımları ele alınmıştir.

Bu çalışma, Antalya ilinin merkez ilçeleri olan; Konyaalt, Muratpaşa, Kepez, Aksu ve Döşemealt'nda gerçekleştirilmiştir. ÇaIışma alanı $30^{\circ}-31^{\circ}$ doğu boylamları ve $36^{\circ}-37^{\circ}$ kuzey enlemleri arasında bulunmaktadır (Şekil 1).

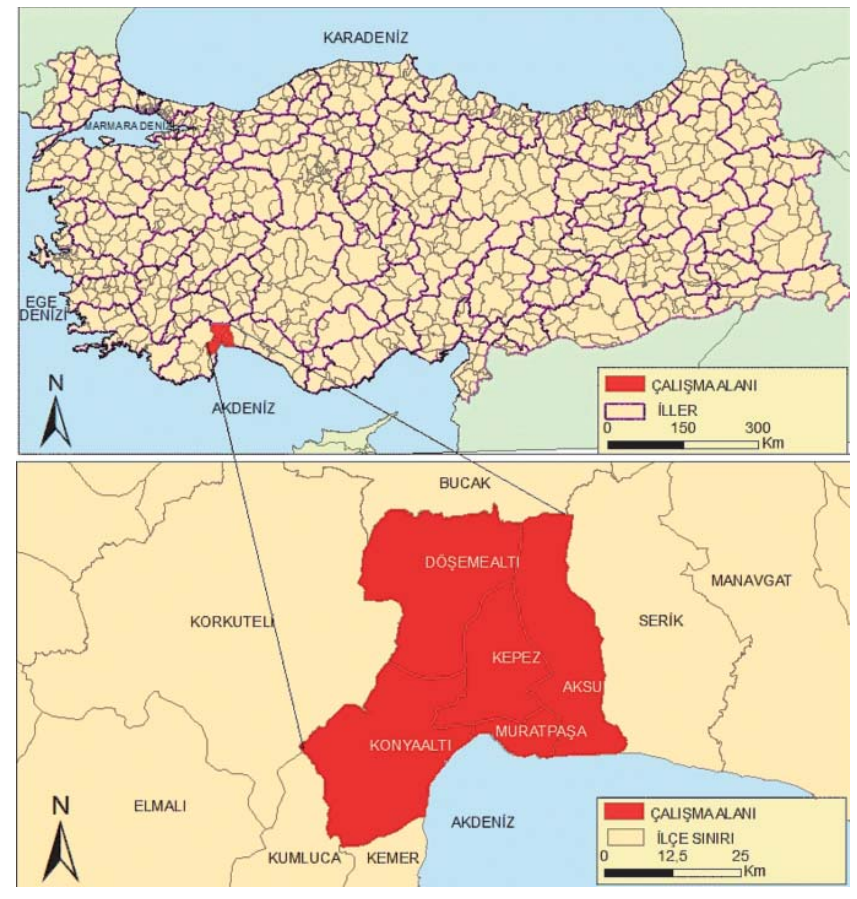

Şekil 1. Çalışma alanının lokasyon haritası. Figure 1. Location map of the study area. 


\section{Antalya ili turizminin arz ve talep durumu}

Türkiye'de hem iç turizmin hem de uluslararası turizmin en çok yöneldiği alan kıyılardır ve talebin yoğunlaştı̆ı kıyı kesimleri de yine ülkenin belirli yerlerinde toplanmıştır . Bu alanlar içerisinde yer alan Antalya, Türkiye'de özellikle yabancı turistlerin en fazla tercih ettiği ildir (Özgüç, 2007). Antalya'ya olan talebin bu kadar fazla olmasında; tarihi turistik çekicilikleri, doğal güzellikleri, orman örtüsünün kıyıya dek uzanması, temiz kumsalları, güneşlenme süresinin uzun olması gibi faktörler etkilidir (Doğanay ve Zaman, 2013).

Antalya ilinin en önemli doğal çekiciliklerini; plajlar, mağaralar, milli parklar, orman alanları, şelaleler, göller, yaylalar, dağlık alanlar oluşturmaktadır. Bunlar içerisinde en önemli çekiciliği; güneş, deniz ve doğanın uyum içerisinde bulunduğu plajlar oluşturmaktadır. İlin; Lara, Konyaalt, Kleopatra, Karpuz Kaldıran, Belek, Kundu, Adalar plajları en önemli olanlarıdır. Ayrıca; Kemer, Tekirova, Kumluca, Finike, Demre ve Kaş kıyılarında iyi olanaklı doğal plajlar bulunmaktadır. 2014 yılı Kültür ve Turizm Bakanlığı istatistiklerine göre Antalya; Mavi Bayraklı Plaj (197) ve Marina (6) sayısı en fazla olan ildir. Antalya ilinde karstik yapıdaki alanların geniş yer kaplamasından dolayı mağaralar fazladır ve bu mağaraların bazıları turizme açıktır, bazıları ise halen turizme açılmayı beklemektedir. Karain, Damlataş, Dim, Beldibi, Altınbeşik ve Kocain mağaraları bunlar içerisinde en önemli olanlardır. Antalya ili; tarihi, arkeolojik ve kültürel değerleri, jeolojik, jeomorfolojik ve hidrolojik yapısı, karstik yer şekilleri, zengin bitki örtüsü ve biyolojik çeşitliliği, farklı özelliklere sahip sulak alanları sayesinde milli parkların fazla olduğu bir konumda bulunmaktadır. Antalya'daki; Beydağları (Olimpos) Sahil Milli Parkı, Köprülü Kanyon Milli Parkı, Termessos (Güllük dağı) Milli Parkı ve Altınbeşik Mağarası Milli Parkı bu bölgeye gelen yerli ve yabancı turistler için alternatif turizm mekânlarını oluşturmaktadır.

Türkiye'de yayla turizmi açısından geniş olanaklara sahip dağlardan birisi de Toros Dağları'dır. Bu dağ kuşağının Antalya Körfezi'nin kuzeyinde kalan kısmı Bat Toroslar'ı oluşturmaktadır. Bat Toroslar, sahip olduğu eşsiz güzellikteki manzaraları, gölleri, ormanları, yaylaları ve alpin çiçeklerle süslü çayırları, bölge sakinlerini Nisan ayından başlayarak, Ekim ayına kadar kendisine çekmektedir. Geleneksel yaylacılık faaliyetlerinde kullanılan yaylalar, günümüzde fonksiyonel değişime uğrayarak, insanların tatillerini geçirdiği sahalar niteliğini kazanmış ve turizm sektöründe değerlendirilmeye başlanmıştır (Zaman, 2007). Çalışma alanında rekreasyonel faaliyetlerin yoğun olarak yapıldığı yaylalar; Saklıkent Yaylası, Ördübek Yaylası, Ovacık Yaylası, Üçoluk Yaylası, Pişer Yaylası, Dereköy Yaylası, İbradı ve Manavgat Yaylaları'dır. Çalışma alanındaki diğer önemli alternatif turizm mekânları ise; Saklıkent ve Tahtalıdağı Kayak Merkezi, Düden ve Manavgat Şelaleleri'dir.

Antalya doğal çekicilikleri yanında, tarihi ve kültürel değerleri bakımından da Türkiye turizminin önemli destinasyonlarından biridir. Antalya'nın yerel kültürü, müzeleri (Antalya, Alanya Arkeoloji, Side, Elmalı, Noel Baba), ören yerleri (Aspendos, Perge, Myra, Xanthos, Patara, Simena, Olympos, Termossoss), kaleleri (Alanya, Syedra), camileri, farklı inançlara ait mekânları, yemekleri, festivalleri, yerli ve yabancı turistler tarafindan en fazla tercih edilen kültürel turizm çekicilikleridir.

Türkiye turizminin en önde gelen destinasyonlarından birisi olan Antalya ilinin yerli ve yabancı turistler tarafindan çok fazla tercih edilmesinde sahip olduğu doğal ve kültürel çekicilikleri yanında, nitelikli turistik tesislerinin de etkisi büyüktür. Emekli (2001)'e göre, 1982 yılından sonra Turizm Teşvik Kanunu ile yabancı sermaye ve özel sektör özendirilerek kalkınma planlarında turizme öncelik verilmesi ile Türkiye'de ve Antalya'daki konaklama tesisleri artmıştir. Uygulanan turizm politikaları ve teşviklerle büyük projeler Akdeniz Bölgesine kaydırılmış ve Türkiye'deki Turizm İşletme Belgeli konaklama tesislerinin bölgesel dağılışında en büyük payı Akdeniz Bölgesi ve özellikle Antalya ili almıştır (Emekli, 2001). Bu tarihten sonra Antalya'ya olan talebin artmasıyla birlikte turizm yatırımlarının da artmaya başladığı görülmektedir. Bu artş̧ı son yıllarda daha fazla olduğu, hatta Türkiye'deki turizm tesislerinin yatak kapasitesi bakımından yaklaşık yarısının Antalya'da olduğu görülmektedir. Türkiye'de 1990 yılında İşletme Belgeli Tesislerin sayısı 237 (\%18,8) iken, 2013 yılında bu sayı 710’a (\%24) çıkmıştır. Geçen 23 yıllık süreçte yatak sayısı 47.299'dan (\%27,3), 362.274'e (\%48,3) yükselmiştir (Tablo 1). Bu tabloya göre, 2013 yılında Antalya ilinin tesis sayısı bakımından Türkiye'deki oranı \%24'dür. Ayrıca, yatak sayısı bakımından da hemen hemen Türkiye'nin yarısı $(\% 48,3)$ orana sahip olması, Antalya'da nitelikli turizm tesislerinin ve yatırımların son yıllarda arttı̆ını göstermektedir.

Turizm olayının en önemli unsurlarından birisi turizm talebidir. Talebe yönelik yapılan tanımlar yazarların kişisel görüşlerine göre farklılık göstermektedir. Örneğin; ekonomistlere göre talep; "belirli bir dönem içerisinde kişilerin belirli bir fiyata almaya gönüllü oldukları mal ve hizmet miktarıdır". Buna karşıt bir görüş olarak, psikoloji uzmanları talebi motivasyon ve davranış bilimlerine dayanarak tanımlamaktadır. Diğer yandan coğrafyacılar, turizm talebini; "sürekli işlerinin ve konutlarının bulunduğu yerden uzak mekânlardaki turistik olanakları ve hizmetleri kullanmak isteyen, seyahat etmekte olan ve/veya seyahat etme eğiliminde olan kişi sayısıdır" şeklinde tanımlamaktadır. Coğrafyacıların tanımı fiyattan farklı olarak başka unsurların da etkisini göz önüne almaktadır (İçöz ve Kozak, 2002). Turistlerin konaklama ve gecelemelerinin yıl içindeki dağılışını bilmek, düşük ve yüksek mevsimlerin belirlenmesini kolaylaştırır. Bu da yöneticileri, o mevsimlerde arzı iyileştirmeye, turistik donatımlardan ve tesislerden daha uzun süre yararlanma yollarını araştırmaya yöneltir. Talebin coğrafi dağılışını tespit etmekle, sık ziyaret edilen yerler ile az sayıda ziyaretçisi olan yerler hakkında bilgi sahibi olunur (Soykan, 2004).

Çalışma alanı olan Antalya, Türkiye'nin hatta son yıllarda dünyanın en fazla talep edilen illerinden birisidir. Türkiye Otelciler Federasyonu (TÜROFED) tarafindan hazırlanan 2013 Turizm Raporu'ndan derlenen bilgilere göre Antalya, dünyada en fazla turist çeken iller sıralamasında yaklaşık 12 milyon yabancı ziyaretçi sayısıyla Londra ve Paris'in ardından üçüncü sıraya yerleşmiştir. Tablo 3'e bakıldığında, Antalya iline olan turist talebi, yerli turistlerden daha çok yabancı turistlerde daha fazla artış oranına sahiptir. Antalya ilinde 2000 yılında, 1.053 .008 yerli, 2.465.092 yabancı turist konaklarken, 2013 yılında 2.966 .418 yerli turist ve 10.827 .657 yabancı turist konaklamıştır (Tablo 2). Geçen 13 yıl içerisinde yerli turist sayısında \%181 artş olurken, yabancı turist sayısında \%339 artş̧ı olduğu görülmektedir. 1990 yılında, Antalya ilinde konaklayan yabancı turist sayısının Türkiye'deki oranı \%16,6'dan, 2013 yılında \%51,1'e çıktığı görülmektedir. Türkiye'ye gelen yabancı turistlerin yarısı Antalya ilini tercih etmekte ve bu oran sürekli artmaktadır. Yerli turistlerin oranı da geçen 23 yılda (1990'da \%5,2 iken, 2013'de 
\%17,3'e yükselmiş) önemli bir şekilde arttı̆ı görülmektedir (Tablo 3). Gerek turizm tesisleri gerekse konaklama göstergelerine bakıldığında, Antalya ilinde belirgin bir şekilde artş̧ görülmektedir. Bu artş̧ın Antalya ilinin gelişimine ve değişimine etkisi büyük olmakla birlikte, turizmin bu gelişiminin çevresel, sosyo-kültürel ve ekonomik etkilerinin sürekli izlenmesi ve oluşan olumsuz etkilerin belirlenmesi, Antalya turizminin sürdü- rülebilirliği açısından önemlidir. Bunun için, bölgede turizmden etkilenen tüm paydaşların görüşleri alınmalı ve alınan sonuçlar doğrultusunda Antalya ili turizmi rasyonel bir şekilde planlanmalıdır. Paydaşlar içerisinde en önemli unsurlardan birisi olan yerel halkın ildeki bu gelişim ve değişime yönelik yaklaşımlarının belirlenmesi hayati önem taşımaktadır.

Tablo 1.1990-2000-2013 yıllarında Antalya ili konaklama işletmelerinin tesis, oda ve yatak sayıları bakımından Türkiye turizmindeki payı

Table 1. The share of the accommodations of Antalya province in Turkey's tourism in terms of the number of facilities, rooms, and beds in the years 1990, 2000, and 2013.

\begin{tabular}{|c|c|c|c|c|c|c|}
\hline & \multicolumn{3}{|c|}{ Turizm Ya tırım Belgeli } & \multicolumn{3}{|c|}{ Turizm İşletme Belgeli } \\
\hline 1990 & Tesis Sayı & Oda Sayı & Yatak Sayı & Tesis Sayı & Oda Sayı & Yatak Sayı \\
\hline Antalya & 456 & 46,366 & 97,315 & 237 & 22,233 & 47299 \\
\hline Türkiye Toplam & 1,921 & 156,702 & 325,515 & 1,260 & 83,953 & 173,227 \\
\hline Antalya Payı (\%) & 23.7 & 29.5 & 29.8 & 18.8 & 26.4 & 27.3 \\
\hline & \multicolumn{3}{|c|}{ Turizm Ya tırım Belgeli } & \multicolumn{3}{|c|}{ Turizm Işletme Belgeli } \\
\hline 2000 & Tesis Sayı & Oda Sayı & Yatak Sayı & Tesis Sayı & Oda Sayı & Yatak Sayı \\
\hline Antalya & 325 & 34,666 & 73,742 & 420 & 54,165 & 114,871 \\
\hline Türkiye Toplam & 1,300 & 113,452 & 243,794 & 1,824 & 156,367 & 325,168 \\
\hline Antalya Payı (\%) & 25 & 30.5 & 30.2 & 23 & 34.6 & 35.3 \\
\hline & \multicolumn{3}{|c|}{ Turizm Ya tırım Belgeli } & \multicolumn{3}{|c|}{ Turizm İşletme Belgeli } \\
\hline 2013 & Tesis Sayı & Oda Sayı & Yatak Sayı & Tesis Sayı & Oda Sayı & Yatak Sayı \\
\hline Antalya & 160 & 34,961 & 77,319 & 710 & 169,080 & 362,274 \\
\hline Türkiye Toplam & 1,056 & 139,928 & 301,862 & 2,982 & 357,440 & 749,299 \\
\hline Antalya Payı (\%) & 15.1 & 30 & 25.6 & 24 & 47.3 & 48.3 \\
\hline
\end{tabular}

Kaynak: Kültür ve Turizm Bakanlığı İstatistikleri, 2015

Tablo 2. Antalya'nın 2000 ve 2013 yılları arası turizm işletme belgeli tesislerde konaklama, geceleme sayısı, ortalama kalış süresi ve doluluk oranı.

Table 2. The number of overnight stays, average accommodation time, and the occupancy rate in the facilities having tourism business license in Antalya province (2000-2013).

\begin{tabular}{|c|c|c|c|c|c|c|c|c|}
\hline \multirow[b]{2}{*}{ Yillar } & \multicolumn{3}{|c|}{ Konaklama Sayısı } & \multicolumn{3}{|c|}{ Geceleme Sayısı } & \multirow{2}{*}{$\begin{array}{l}\text { Ort. } \\
\text { Kalış } \\
\text { Süre }\end{array}$} & \multirow{2}{*}{$\begin{array}{c}\text { Doluluk } \\
\text { Oranı } \\
(\%)\end{array}$} \\
\hline & Yabancı & Yerli & Toplam & Yabancı & Yerli & Toplam & & \\
\hline 2000 & $2,465,092$ & $1,053,008$ & $3,518,100$ & $15,988,047$ & $3,448,736$ & $19,476,781$ & 5.5 & 46.4 \\
\hline 2001 & $3,507,343$ & 829,762 & $4,337,105$ & $20,317,171$ & $2,466,288$ & $22,783,459$ & 5.3 & 61.5 \\
\hline 2002 & $4,050,824$ & 864,601 & $4,915,425$ & $25,289,860$ & $2,836,846$ & $28,126,706$ & 5.7 & 63.3 \\
\hline 2003 & $4,051,378$ & $1,021,436$ & $5,072,817$ & $24,150,945$ & $3,203,644$ & $27,354,589$ & 5.4 & 59.6 \\
\hline 2004 & $5,027,822$ & $1,223,356$ & $6,251,178$ & $30,820,639$ & $3,742,410$ & $34,563,049$ & 5.5 & 64 \\
\hline 2005 & $5,314,451$ & $1,232,481$ & $6,546,932$ & $33,547,895$ & $3,548,997$ & $37,096,892$ & 5.7 & 63.9 \\
\hline 2006 & $5,661,890$ & $1,697,005$ & $7,358,895$ & $28,248,012$ & $4,676,279$ & $32,924,291$ & 4.5 & 57 \\
\hline 2007 & $7,070,077$ & $1,689,949$ & $8,760,026$ & $35,354,560$ & $4,873,596$ & $40,228,156$ & 4.6 & 62.1 \\
\hline 2008 & $6,174,161$ & $1,371,459$ & $7,545,620$ & $35,850,931$ & $3,949,280$ & $39,807,211$ & 5.3 & 63.3 \\
\hline 2009 & $6,968,975$ & $1,871,527$ & $8,840,502$ & $38,418,577$ & $5,408,876$ & $43,827,453$ & 5 & 58.9 \\
\hline 2010 & $8,695,231$ & $2,257,463$ & $10,952,694$ & $49,264,226$ & $6,626,632$ & $55,890,858$ & 5.1 & 58.5 \\
\hline 2011 & $9,454,362$ & $2,272,239$ & $11,726,601$ & $50,978,182$ & $6,836,384$ & $57,814,566$ & 4.9 & 58.4 \\
\hline 2012 & $10,183,562$ & $2,603,361$ & $12,786,923$ & $60,373,209$ & $7,664,494$ & $68,037,703$ & 5.3 & 63.2 \\
\hline 2013 & $10,827,654$ & $2,966,418$ & $13,794,072$ & $57,691,550$ & $8,685,148$ & $66,373,698$ & 4.8 & 61.1 \\
\hline
\end{tabular}

Kaynak: Kültür ve Turizm Bakanlığı İstatistikleri, 2015.

Tablo 3. Antalya'nın 2000 ve 2013 yıllarında turizm işletme belgeli tesislerde konaklama, geceleme sayısı, ortalama kalış süresi ve doluluk oranı bakımından Türkiye turizmindeki payı.

Table 3. The share of Antalya province in Turkey's tourism in terms of accommodation, the number of overnight stays, average accommodation time, and occupancy rate in the facilities having tourism business license between 2000 and 2013.

\begin{tabular}{|c|c|c|c|c|c|c|c|c|}
\hline \multirow[b]{2}{*}{1990} & \multicolumn{3}{|c|}{ Konaklama Sayısı } & \multicolumn{3}{|c|}{ Geceleme Sayısı } & \multirow{2}{*}{$\begin{array}{c}\text { Ort. Kalış } \\
\text { Süre } \\
\end{array}$} & \multirow{2}{*}{\begin{tabular}{|l|} 
Doluluk \\
Oranı (\%) \\
\end{tabular}} \\
\hline & Yabanci & Yerli & Toplam & Yabancı & Yerli & Toplam & & \\
\hline Antalya & 644,293 & 188,604 & 832,897 & $5,006,065$ & 617,202 & $5,623,267$ & 6.7 & \\
\hline Türkiye & $3,869,166$ & $3,584,287$ & $7,453,453$ & $13,270,641$ & $6,878,368$ & $20,149,009$ & 2.7 & \\
\hline \multirow[t]{2}{*}{$\operatorname{Pay}(\%)$} & 16.6 & 5.2 & 11.1 & 37.7 & 8.9 & 27.9 & & \\
\hline & \multicolumn{3}{|c|}{ Konaklama Sayısı } & \multicolumn{3}{|c|}{ Geceleme Sayısı } & Ort. Kalış & \\
\hline 2013 & Yabanci & Yerli & Toplam & Yabancl & Yerli & Toplam & Süre & Oranı (\%) \\
\hline Antalya & $10,827,654$ & $2,966,418$ & $13,794,072$ & $57,691,550$ & $8,685,148$ & $66,376,698$ & 4.8 & 61.1 \\
\hline Türkiye & $21,181,668$ & $17,100,765$ & $38,282,433$ & $89,594,261$ & $33,090,923$ & $122,685,184$ & 3.2 & 52.6 \\
\hline Pay (\%) & 51.1 & 17.3 & 36 & 64.3 & 26.2 & 54.1 & & \\
\hline
\end{tabular}

Kaynak: Kültür ve Turizm Bakanlığı İstatistikleri, 2015 


\section{Amaç ve yöntem}

Bu çalışma, Antalya ili turizminin gelişimine, etkilerine ve değişimine Antalya merkez ilçelerinde yaşayan yerel halkın nasıl baktığını ve yerel halkın bu konudaki algılarının cinsiyete ve yaş gruplarına göre farklılık gösterip göstermediğini belirlemeği amaçlamaktadır. Çalışmada veri toplama yöntemi olarak anket yöntemi seçilmiştir. Turizm faaliyetlerini, aktivitelerini ve değişimlerini okumak ve değerlendirmek için anketler önemli bir veri kaynağı oluşturmaktadır. Turizm ve rekreasyon faaliyetlerini gerçekleştiren insan olduğu için turistlerin ve yerel halkın düşünceleri ve bakış açıları, o bölgenin turizm ve rekreasyon potansiyelinin yorumlanmasında önemli bir yer tutar. Araştırmanın evrenini Antalya ili merkez ilçelerinde (Konyaalt, Muratpaşa, Kepez, Aksu ve Döşemealt) yaşayan 1.203.994 (Tablo 4) kişi oluşturmaktadır. Araştırmanın evreni belirlenirken Türkiye İstatistik Kurumu (TÜiK) 2014 yılı Adrese Dayalı Nüfus Kayıt Sistemi veri tabanı kullanılmıştır. Çalışmada ana kütleyi oluşturan birey sayısının fazla olması, zaman ve maliyet gibi sınırlılık nedeniyle örnekleme yoluna gidilmiştir. Yazıcıoğlu ve Erdoğan'ın (2004) belirlediği ölçeğe göre çalışma alanının örneklem hacmi, $\pm \% 95$ güven aralığında, $\pm \% 5$ yanılma payı ile 384 kişiye karşılık gelmektedir. Antalya ili merkez ilçelerinde yaşayan yerel halka yönelik geliştirilen anket, tesadüfi olarak belirlenen 488 farklı kişiye uygulanmıştır. Hatalı ve eksik doldurulan anket formları değerlendirmeye alınmamıştır, toplamda 464 adet anket çalışmaya dâhil edilmiştir.

Tablo 4. Çalışma alanının nüfus sayıları ve uygulanan anket sayıları.

Table 4. The population and the number of surveys conducted in the study area.

\begin{tabular}{|c|c|c|}
\hline MERKEZ iLÇELER & ANKET SAYISI & NÜFUS SAYISI \\
\hline Muratpaşa & 165 kişi & 465,927 \\
\hline Konyaaltı & 79 kişi & 145,648 \\
\hline Kepez & 118 kişi & 470,759 \\
\hline Aksu & 61 kişi & 68,106 \\
\hline Döşemealtı & 41 kişi & 53,554 \\
\hline
\end{tabular}

Araştırma evreninden örnekleme yöntemi olarak basit tesadüfi örnekleme yöntemi kullanılarak veriler toplanmıştır. Ankete kathlacak kişilere öncelikle araştırmacı tarafindan araştırma hakkında katılımcılara kısa bir bilgi sunumu yapıldıktan sonra veri toplama araçları gönüllü olan katılımcılara verilmiştir. Katılımcılara uygulanan anket iki bölümden oluşmaktadır. Anketin araştırmacı tarafindan geliştirilen birinci bölümünde, katılımcıların kişisel özelliklerine yönelik sorular yer almaktadır. Araştırmacı tarafindan geliştirilen ikinci bölümde ise Antalya'da yerli halkın turizm faaliyetlerine bakışı ile ilgili sorular yöneltilmiştir. Anket formlarından elde edilen veriler SPSS 20.00 programı kullanılarak; frekans analizi, Mann-Whitney U testi ve KruskallWallis analizi ile test edilmiştir. Çalışmada ayrıca Antalya'nın Türkiye turizmindeki yeri sayısal veriler kullanılarak değerlendirilmiştir.

\section{Bulgular}

Çalışmada kullanılan anket formu iki bölümden oluşmaktadır. Birinci bölümde, ankete katılanların cinsiyet, yaş aralığı, meslek, gelir, eğitim ve medeni durumu gibi demografik bilgilere ilaveten katılımcıların kaç yıldır Antalya ilinde yaşadıklarına ilişkin bilgiler yer almaktadır. Anket formunun ikinci bölümünde ise, katlımcıların Antalya merkez ilçelerinde sürdürülebilir turizm ve yerel halkın turizmin etkilerine yaklaşımının belirlenmesine yönelik geliştirilen ifadeler yer almaktadır. Anket formunun ikinci bölümünde yer alan ifadeler; "1: Kesinlikle Katılıyorum 3: Kararsızım - 5: Kesinlikle Katımıyorum" sıra düzeni ile beşli "Likert" türünde hazırlanmıştır. Dolayısıyla, veriler niteldir ve normal dağılmamaktadır, bu nedenle nitel veriler için parametrik olmayan (Yeşiltaş ve Demirçivi, 2010) testler uygulanmıştir. Bireylerin Antalya merkez ilçelerinde sürdürülebilir turizm ve yerel halkın turizmin etkilerine yaklaşımının etkilerine ilişkin görüşlerinin; cinsiyet durumuna göre farklılaşıp farklılaşmadığı Mann-Whitney U testi ile, yaş grubu durumlarına göre farklılaşıp farklılaşmadığı ise Kruskall-Wallis testi ile sınanmıştır. Çalışmada kullanılan istatistiksel analizlerin anlamlılık derecesini belirlemede 0,05 anlamlılık düzeyi kabul edilmiştir. Çalışmada öncelikle, anketi cevaplayan bireylerin demografik özellikleri ile anket formunun ikinci bölümünde yer alan ifadelere katılımlarına ilişkin verilerin normal dağılım gösterip göstermediğini belirlemek amacıyla Kolmogorov-Smirnov testi uygulanmıştir. Test sonucunda çalışmada kullanılan verilerin anlamlılık değerlerinin tümünün $(p<0,05)$ 0,05'den küçük olduğu görülmüş, bu durumda verilerin normal dağılmadığı tespit edilmiştir.

Veri analizlerine geçilmeden önce yapılması gerekenlerden bir tanesi de verilerin analize hazır hale getirilmesidir. Geçerliliği ve güvenirliği sağlamada verilerin analize hazır hale getirilmesi oldukça önemlidir. Bu nedenle veri analizlerine geçilmeden önce veri setinde hatalı, yanlış kodlama gibi bazı nedenlerden kaynaklanabilecek sorunları gidermeye yönelik veri seti üzerinde birtakım veri temizleme işlemleri yapılmıştır.

Tablo 5'de katılımcıların demografik özelliklerine ilişkin bilgileri yer almaktadır. Araştırmaya katılan bireylerin cinsiyetlerine göre dağılımı incelendiğinde, katılımcıların \%62'sinin erkek, \%37.9'unun ise bayanlardan oluştuğu görülmektedir. Anketin ağırlıklı olarak esnaflara uygulanması, bunda etkili olan bir faktördür.

Araştırmaya katılan bireylerle ilgili diğer demografik bulgular incelendiğinde; katlımcıların \%27'sinin 20-30 yaş grubu aralığında, \%32'sinin 31-40, \%33'ünün 41-50, \%5'inin 51-60 ve son olarak \%3'ünün 61 yaş ve üzeri yaş grubu aralığında olduğu görülmektedir. Eğitim durumuna bakıldığında ise katılımcıların; ilköğretim (ilk ve ortaokul) \%18, lise mezunları \%31, lisans ve ön lisans mezunlarının \% 41 ve lisansüstünün \%10 olduğu görülmektedir. Katılımcıların büyük çoğunluğunun (\%65) evli olduğu anlaşılmaktadır. Meslek dağılımları incelendiğinde ise; iş̧̧i, tüccar, memur, serbest meslek, esnaf ve emekli olanların birbirlerine yakın oransal dağılıma ( $\pm \% 10)$ sahip oldukları görülmektedir (Tablo 5).

Katilımcıların gelir durumlarına bakıldığında, \%14'ünün 550 TL'nin altinda, \%9'unun 551-1000, \%16'sının 1001-1500, $\% 19$ 'unun $1501-2000$, \%22'sinin 2001-3000, \%9'unun 30014000 TL aralığında ve \%9'unun ise 4001 TL'nin üzeri gelirinin olduğu görülmektedir.

Antalya'da kalma sürelerinin oransal dağılımına bakılacak olursa katılımcıların yarısının 20 yıldan fazla Antalya'da ikamet ettiği görülmektedir. Katılımcıların \%7'si bir yıldan daha az, \%14'ü 1-5 yıl, \%10'u 6-10 yıl, \%8'i 11-15 yıl ve \%11'i ise 16-20 yıldır Antalya'da yaşamaktadır (Tablo 6). Bu tabloya göre anketin düzenlendiği Antalya'nın merkez ilçelerinin dışarıdan önemli derecede göç aldığı görülmektedir. 
Tablo 5. Ankete katılanların demografik özelliklerine ilişkin bilgiler. Table 5. Demographic characteristics of the survey participants.

\begin{tabular}{|c|c|c|c|}
\hline & & Frekans & Yüzdelik \\
\hline \multirow{4}{*}{ Cinsiyet } & Erkek & 288 & 62 \\
\hline & Kadın & 176 & 38 \\
\hline & Toplam & 464 & 100 \\
\hline & & Frekans & Yüzdelik \\
\hline \multirow{7}{*}{ Yaş grupları } & $20-30$ & 127 & 27 \\
\hline & $31-40$ & 148 & 32 \\
\hline & $41-50$ & 154 & 33 \\
\hline & $51-60$ & 22 & 5 \\
\hline & 61 ve üzeri & 11 & 3 \\
\hline & Toplam & 464 & 100 \\
\hline & & Frekans & Yüzdelik \\
\hline \multirow{7}{*}{ Eğitim durumu } & illköğretim & 83 & 18 \\
\hline & Lise & 145 & 31 \\
\hline & Ön Lisans & 88 & 19 \\
\hline & Lisans & 103 & 22 \\
\hline & Yüksek Lisans-doktora & 44 & 10 \\
\hline & Toplam & 464 & 100 \\
\hline & & Frekans & Yüzdelik \\
\hline \multirow{5}{*}{ Medeni durum } & Evli & 303 & 65 \\
\hline & Bekâr & 157 & 34 \\
\hline & Diğer & 4 & 1 \\
\hline & Toplam & 464 & 100 \\
\hline & & Frekans & Yüzdelik \\
\hline \multirow{12}{*}{ Mesleki durum } & Çiftçi & 49 & 11 \\
\hline & Tüccar & 15 & 3 \\
\hline & Esnaf & 108 & 23 \\
\hline & Serbest Meslek & 44 & 10 \\
\hline & İşçi & 37 & 8 \\
\hline & Devlet Memuru & 40 & 9 \\
\hline & Emekli & 19 & 4 \\
\hline & Öğrenci & 53 & 11 \\
\hline & Ev Hanımı & 49 & 11 \\
\hline & Diğer & 46 & 10 \\
\hline & Toplam & 460 & 100 \\
\hline & & Frekans & Yüzdelik \\
\hline \multirow{8}{*}{ Gelir Durumu } & 550 'den az & 67 & 15 \\
\hline & $551-1000$ arası & 43 & 10 \\
\hline & $1001-1500$ arası & 73 & 16 \\
\hline & $1501-2000$ arası & 89 & 19 \\
\hline & $2001-3000$ arası & 104 & 22 \\
\hline & $3001-4000$ arası & 39 & 9 \\
\hline & 4001 ve üzeri & 42 & 9 \\
\hline & Toplam & 457 & 100 \\
\hline
\end{tabular}

Tablo 6. Bireylerin Antalya ilinde yaşadıkları yıllara göre dağılımı. Table 6. How long have the survey respondents been residing in Antalya province?

\begin{tabular}{|l|c|c|}
\hline & Frekans & Yüzdelik \\
\hline 1 yıldan daha az & 32 & 7 \\
\hline $1-5$ yıl & 64 & 14 \\
\hline $6-10$ yıl & 47 & 10 \\
\hline $11-15$ yıl & 37 & 8 \\
\hline $16-20$ yıl & 51 & 11 \\
\hline 21 yıl ve üzeri & 233 & 50 \\
\hline Toplam & 464 & 100 \\
\hline
\end{tabular}

Ankette kullanılan beşli dereceleme ölçeğine uygun olarak elde edilen ortalama puanların yorumlanması ve derecelendirilmesi, Tablo 7'de verilen puan sınırları kriterine göre değerlendirilmiştir. Tabloda yer alan puan sınır değerleri, bireylerin anket formunda yer alan ifadelere katılma durumlarına ait cevapların aritmetik ortalamasının eşit dört aralığını ifade etmektedir.
Tablo 7. Anket sorularının pun sınırları.

Table 7. Rate limits of the survey.

\begin{tabular}{|l|c|c|}
\hline & Puan & Ortalama aralığı \\
\hline Kesinlikle katılıyorum & 1 & $1.00-1.79$ \\
\hline Katılıyorum & 2 & $1.80-2.59$ \\
\hline Kararsızım & 3 & $2.60-3.39$ \\
\hline Katılmıyorum & 4 & $3.40-4.19$ \\
\hline Kesinlikle katılmıyorum & 5 & $4.20-5.00$ \\
\hline
\end{tabular}

Ankete katılanların, Antalya'daki turizmin gelişimine, etkilerine ve sürdürülebilirliğine yönelik ifadelere katılım dereceleri Tablo 8'de verilmiştir. Buna göre, anketi dolduran bireylerin "Antalya'ya daha fazla turistin gelmesini istiyorum" ifadesinin çok yüksek katılım gösterdiği görülmüştür. Bu durum, ankete kat-lan bireylerin, Antalya'daki turizmin gelişimine verdikleri önemi göstermesi açısından önemlidir.

Ankete cevap veren bireyler "Antalya'ya daha çok turist değil daha nitelikli turist gelmesini istiyorum" ve "Antalya'ya gelen turistin nitelikli olması turizme daha fazla katkı sağlayacağını düşünüyorum" ifadelerine yüksek derecede katılım göstermektedir. Antalya turizmi gerek ülkemizde gerekse dünyada belli bir gelişim sevisine ulaşmıştır. Katılımcıların verdiği cevaplara göre, bundan sonraki süreçte ilde turizmin daha sağlıklı gelişmesi için nitelikli turist sayısının artırılması ve buna yönelik planlamaların yapılması gerektiği anlaşılmaktadır. Ayrıca ankete katılanların, "Antalya'ya yerli turistten çok yabancı turistin gelmesini istiyorum" ve "Antalya'ya gelen yerli turistin yeterince bilinçli olduğunu düşünmüyorum" ifadelerine yüksek derecede katılım göstermesi, yerel halkın yerli turistten yeteri kadar memnun olmadığı ve yabancı turistten daha fazla fayda sağladığı anlamını ortaya çıkarmaktadır. "Antalya'da turizm yatırımlarının halkın yaşam standartlarını yükselttiğini düşünüyorum" ve "Antalya'da halkın turizm sayesinde birçok sosyal etkinlikten (konser-festival) yararlandığını düşünüyorum" ifadelerine de ankete katılanların yüksek derecede katılımının olması, yerel halkın Antalya'da turizmin gelişiminden olumlu yönde etkilendiğini göstermektedir.

Bununla birlikte ankete katılanların anket sorularına verdikleri cevaplara bakıldığında, yerel halkın Antalya'daki turizmin gelişimine genelde olumlu olarak baktıkları gibi, turizmin bazı olumsuz etkilerinin de olduğu ve bu olumsuz etkilerin ilin çevresel, ekonomik ve sosyal hayatını olumsuz etkilediği sonucu da ortaya çıkmaktadır. Ankete katilanların; "Antalya'daki kontrolsüz turizm büyümesi çevresel sorunlar meydana getirmektedir", "Antalya'da kontrolsüz yapılaşmanın şehirde görüntü kirliliği meydana getirdiğini düşünüyorum”, "Antalya'daki turistik tesislerin çevreci olduğunu düşünmüyorum”, "Antalya'da turizmin gelişmesiyle hayat şartlarının zorlaşthğını düşünüyorum", "Antalya'daki turizm sayesinde arazi, konut, mal ve hizmet fiyatlarının artışa uğradığını düşünüyorum" ifadelerine katılım derecelerinin de yüksek olması; yerel halkın Antalya turizminin olumsuz etkilerinin farkında olması ve bundan rahatsız olması açısından önemlidir. Bu durum, Antalya merkez ilçelerinde yaşayan yerel halkın, turizmin ekonomik, toplumsal, fiziksel ve çevresel faydaları konularında sahip oldukları bilincini ve Antalya'da turizmin sürdürülebilir bir şekilde gelişme göstermesi konusundaki beklentilerini göstermektedir (Tablo 8). 
Anketi cevaplayan bireylerin "Antalya'da turizmin daha fazla gelişmesini istemiyorum" ifadesine katılım derecesi ise düşük olarak gerçekleşmiştir. Bu sonuçlar, yerel halkın genel olarak turizme ve Antalya turizminin gelişimine verdiği önem ile ilgili ifadelere katılım dereceleri ile uyumludur.

Çalışmada ayrıca, Antalya merkez ilçelerinde yaşayan yerel halkın Antalya turizminin gelişimine ve etkilerine bakış açısının cinsiyet durumuna ve yaş gruplarına göre farklı olup olmadığı analiz edilmiştir. Bunun için ankete katılanların cinsiyet durumuna göre anlamlı farklılık gösterip göstermediği Mann-Whitney $U$ testi ve yaş gruplarına göre anlamlı farklılık olup olmadığı için ise Kruskal-Wallis testi uygulanmıştır. Ayrıca istatistiksel olarak anlamlı farklılığın hangi gruplar arasında olduğu analiz edilmiştir.

Veriler normal dağılım özelliği göstermiyorsa, homojen değilse ve örneklem büyüklüğü az ise Mann-Whitney $U$ testi kullanılması gerekir (Baş, 2010). Mann-Whitney U testi, iki ilişkisiz grubun ilgilenilen değişken bakımından evrende benzer dağılımlara sahip olup olmadığını test eder. Kruskal -Wallis tekniği ise, ilişkisiz iki ya da daha çok örneklem ortalamasının birbirinden anlamlı farklılık gösterip göstermediğini test eder. Her iki test parametrik olmayan (Non-Parametrik) veriler için kullanılır (Büyüköztürk, 2013).

Anket sorularını cevaplayan bireylerin cinsiyetleri ile bireylerin Antalya turizmine yönelik değerlendirmelerini içeren ifadelere verdikleri cevapların dağılımları arasında istatistiksel olarak anlamalı farklılığın olup olmadığını araştırmak amacıyla MannWhitney $U$ testi uygulanmıştir. Uygulanan Mann-Whitney $U$ testi sonuçlarına göre, ankete cevap veren bireylerin cinsiyete göre ankete verilen cevaplarının hiçbir ifadede anlamlı düzeyde farklılaşmadığı görülmüştür (Tablo 9).

Anket sorularını cevaplayan bireylerin, yaş grupları ile Antalya ilindeki turizme yönelik değerlendirmelerine ilişkin ifadelere verdikleri cevapların istatistiksel olarak anlamlı farklılığın olup olmadığını test edilmiştir. Katılımcılar tarafindan cevaplanan anket formunun demografik bilgiler bölümünde yer alan yaş aralıkları 5 grupta derlendiğinden, ikiden fazla grup ortalaması arasındaki farkın test edilmesinde yaygın olarak kullanılan Kruskal -Wallis testi uygulanmıştır. Uygulanan Kruskal -Wallis testi sonucunda istatistiksel olarak anlamlı farklılıkların bulunduğu yaş grupları Tablo 10'da yer alan "Gruplar Arası Anlamlı Fark" sütununda özetlenmiştir.

Ankete cevap veren bireylerin yaş gruplarına göre anket formunun ikinci bölümünde yer alan ifadelere katlım ortalamaları arasında istatistiksel olarak anlamlı farklılığın ortaya çıktığı görülmektedir. Yaş gruplarının sıra ortalamaları dikkate alındığında, en yüksek ortalamaya 20-30 yaş grubunun, en düşük ortalamaya ise 61 ve üzeri yaş aralığında olduğu görülmektedir. Test sonucunda istatistiksel olarak anlamlı farklılıkların ortaya çıktı̆ı ifadelerin; "Antalya'daki turistik tesislerin çevreci olduğunu düşünmüyorum ( $p=0,048)$ ", "Antalya'ya yerli turistten daha çok yabancı turistin gelmesini istiyorum $(p=0,004)$ ", "Antalya'da turizmin çevreye zararının olduğunu düşünmüyorum $(p=0,002)$ ", "Antalya'da turizm yatırımlarının halkın yaşam standartlarını yükselttiğini düşünüyorum $(p=0,002)$ ”, "Antalya'daki son dönem turizm politikaları ve yatırımlarının çevre koruma eksenli büyüdüğünü düşünüyorum ( $p=0,025)$ ”, “Antalya'da halkın turizm sayesinde birçok sosyal etkinlikten (konser-festival) yararlandığını düşünüyorum ( $p=0,011)$ ”, “Antalya'nın yaşanabilir bir turizm kenti olduğunu düşünmüyorum $(p=0,007)$ " şeklinde olduğu gözlenmiştir (Tablo 10). Buna göre Antalya turizminin gelişimi ve etkilerine yönelik hazırlanan 19 anket sorusundan yedisinde yaş gruplarına göre anlamlı farklılık görülürken, 12 soruda herhangi bir anlamlı farklılık bulunmamaktadır. Ankete katılanların verdiği cevaplara göre, Antalya merkez ilçelerinde yaşayan yerel halkın, çalışma alanındaki turizmin gelişimi ve etkilerine yönelik; özellikle turizmin çevresel etkileri ve Antalya'ya yerli turistin mi yoksa yabancı turistin mi gelmesi gerektiği konularında yaş gruplarına göre farklı bakış açılarına sahip olduğu görülmektedir.

Tablo 8. Ankete katılanların Antalya'da turizme yönelik tutumlarına ilişkin ifadelere katılma dereceleri.

Table 8. The attitudes of the survey participants towards tourism in the province of Antalya.

\begin{tabular}{|c|c|c|c|c|}
\hline & $\mathbf{N}$ & $\begin{array}{l}\text { Aritmetik } \\
\text { Ort. (X) }\end{array}$ & $\begin{array}{c}\text { Standart } \\
\text { sapma }\end{array}$ & $\begin{array}{c}\text { Katılım } \\
\text { Derecesi }\end{array}$ \\
\hline Antalya'ya daha fazla turistin gelmesini istiyorum & 464 & 1,75 & 1,055 & Çok Yüksek \\
\hline Antalya'da daha çok turist değil daha nitelikli turist gelsin istiyorum & 464 & 1,82 & 1,011 & Yüksek \\
\hline Antalya’ya gelen yerli turistin yeterince bilinçli olduğunu düşünmüyorum & 464 & 1,84 & 0,977 & Yüksek \\
\hline Antalya’ya gelen turistin nitelikli olmasının turizme daha fazla katkı sağlayacağını düşünüyorum & 464 & 1,86 & 0,975 & Yüksek \\
\hline Antalya'da kontrolsüz yapılaşma şehirde görüntü kirliliği meydana getirdiğini düşünüyorum & 464 & 2,02 & 1,153 & Yüksek \\
\hline Antalya'da ki kontrolsüz turizm büyümesi çevresel sorunlar meydana getirmektedir & 464 & 2,07 & 1,158 & Yüksek \\
\hline Antalya'daki turizm sayesinde arazi, konut, mal ve hizmet fiyatlarının artışa uğradığını düşünüyorum & 464 & 2,11 & 1,106 & Yüksek \\
\hline Antalya'daki turistik tesislerin çevreci olduğunu düşünmüyorum & 464 & 2,21 & 1,126 & Yüksek \\
\hline Antalya'da turizmin gelişmesiyle hayat standartlarının pahalılaştığını düşünüyorum & 464 & 2,21 & 2,672 & Yüksek \\
\hline Antalya'da halkın turizm sayesinde birçok sosyal etkinlikten (konser-festival)yararlandığını düşünüyorum & 464 & 2,27 & 1,061 & Yüksek \\
\hline Antalya'da Turizm yatırımlarının halkın yaşam standartlarını yükselttiğini düşünüyorum & 464 & 2,44 & 1,029 & Yüksek \\
\hline $\begin{array}{l}\text { Antalya'da sahillerde uygulanan mavi bayrak uygulaması sahillerin daha temiz ve kullanılabilirliğini artırdığını } \\
\text { düşünüyorum }\end{array}$ & 464 & 2,52 & 1,127 & Yüksek \\
\hline Antalya ya yerli turistten çok yabancı turistin gelmesini istiyorum & 464 & 2,56 & 1,407 & Yüksek \\
\hline Antalya'da ki mevcut turizm planlaması ve politikası; doğal kaynakların sürdürülebilirliğini destekler niteliktedir. & 464 & 2,83 & 1,384 & Orta \\
\hline Antalya'da ki son dönem turizm politikaları ve yatırımlarının çevre koruma eksenli büyüdüğünü düşünüyorum & 464 & 2,87 & 1,378 & Orta \\
\hline Antalya'da ki yaşam standartları sadece turistler için yüksektir yerel halkı kapsadığını düşünmüyorum & 464 & 2,90 & 1,094 & Orta \\
\hline Antalya’da ki yaşam standartlarının diğer illerden farklı olmadığını düşünüyorum & 464 & 3,05 & 1,071 & Orta \\
\hline Antalya'nın yaşanabilir bir turizm kenti olduğunu düşünmüyorum & 464 & 3,26 & 1,074 & Orta \\
\hline Antalya'da turizmin çevreye zararının olduğunu düşünmüyorum & 464 & 3,31 & 1,219 & Orta \\
\hline Antalya'da turizmin daha fazla gelişmesini istemiyorum & 464 & 3,52 & 1,486 & Düşük \\
\hline
\end{tabular}


Tablo 9. Ankete katlanların cinsiyete göre Antalya'da turizme yönelik tutumlarına ilişkin ifadelere katılım dağılımları Mann-Whitney U testi sonuçları. Table 9. The attitudes of the survey participants towards tourism in the province of Antalya by gender.

\begin{tabular}{|c|c|c|c|c|c|}
\hline & Cinsiyet & $\mathrm{N}$ & $\begin{array}{c}\text { Sira } \\
\text { Ortalama }\end{array}$ & Sum of Ranks & P Degereri \\
\hline \multirow{2}{*}{ Antalya'ya daha fazla turistin gelmesini istiyorum } & Bay & 288 & 233,31 & 67194,00 & \multirow[t]{2}{*}{0,854} \\
\hline & Bayan & 176 & 231,17 & 40686,00 & \\
\hline \multirow{2}{*}{ Antalya'da daha çok turist deछ̈il daha nitelikli turist gelsin istiyorum } & Buy & 288 & 228,87 & 65913,50 & \multirow[t]{2}{*}{0,419} \\
\hline & Buyan & 176 & 238,45 & 41966,50 & \\
\hline \multirow{2}{*}{ Antalya'ya gelen yerli turistin yeterince bilinçli alduğunu düşünmüyorum } & Bay & 288 & 226,81 & 65321,50 & \multirow[t]{2}{*}{0,22} \\
\hline & Buyan & 176 & 241,81 & 42558,50 & \\
\hline \multirow{2}{*}{ 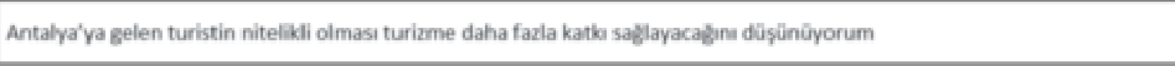 } & Bay & 288 & 240,11 & 69151,50 & \multirow[t]{2}{*}{0,092} \\
\hline & Buyan & 176 & 220,05 & 39728,50 & \\
\hline \multirow{2}{*}{ Antalya ya verli turistten çok yabanca turistin gelmesini istiyorum } & Buy & 288 & 229,90 & 66211,00 & \multirow[t]{2}{*}{0,579} \\
\hline & Bayan & 176 & 236,76 & 41669,00 & \\
\hline \multirow{2}{*}{ Antalya'da ki kontrolsüz turizm būyûmesi çewresel sorunlar meydana getirmektedir } & Bay & 288 & 235,29 & 67763,50 & \multirow[t]{2}{*}{0,351} \\
\hline & Bayan & 176 & 227,93 & 40116,50 & \\
\hline \multirow{2}{*}{ Antalva'da kontrolsūz vapilaşma sehirde görüntũ kirlilig̨i meydana getirdigini düşünūyorum } & Bay & 288 & 237,67 & 68449,00 & \multirow[t]{2}{*}{0,546} \\
\hline & Bayan & 176 & 224,04 & 39431,00 & \\
\hline \multirow{2}{*}{ Antalya'daki turistik tesislèrin çevreci olduğunu düyûnmüyorum } & Bay & 288 & 226,78 & 65314,00 & \multirow[t]{2}{*}{0,814} \\
\hline & Bayan & 176 & 241,85 & 42566,00 & \\
\hline \multirow{2}{*}{ Antalya'da turizmin çevreve zaranın olduğunu düşünmüyorum } & Bay & 288 & 234,32 & 67484,00 & \multirow[t]{2}{*}{0,68} \\
\hline & Bayan & 176 & 234,32 & 40396,00 & \\
\hline \multirow{2}{*}{ Antalya'da Turizm yatırımlarınin halkan vaşam standartlarını yūkselttig̈ini dūşünüyorum } & Bay & 288 & 237,48 & 68393,50 & \multirow[t]{2}{*}{0,088} \\
\hline & Bayan & 176 & 224,36 & 39486,50 & \\
\hline \multirow{2}{*}{ Antalya'nın yaşanabilir bir turiam kenti olduğunu dūsūnmmūyorum } & Bay & 288 & 226,32 & 65179,50 & \multirow[t]{2}{*}{0,288} \\
\hline & Bayan & 176 & 242,62 & 42700,50 & \\
\hline \multirow{2}{*}{ Antalya'da turizmin daha fazla geligmesini istemiyorum } & Buy & 288 & 230,36 & 66344,00 & \multirow[t]{2}{*}{0,561} \\
\hline & Bayan & 176 & 236,00 & 41536,00 & \\
\hline \multirow{2}{*}{ Antalya'da turiamin gelig̨meshye hayat standartlarinin pahalilaştoğını düşünulyorum } & Bay & 288 & 240,34 & 69216,50 & \multirow[t]{2}{*}{0,646} \\
\hline & Buyan & 176 & 219,68 & 38663,50 & \\
\hline 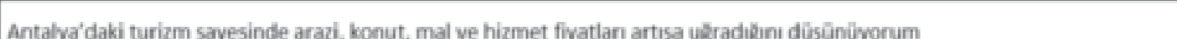 & Bay & 288 & 239,95 & 69106,50 & 0,092 \\
\hline & Bayan & 176 & 220,30 & 38773,50 & \\
\hline 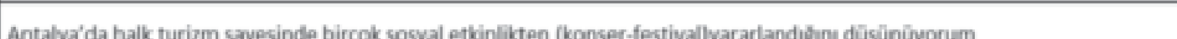 & Bay & 288 & 239,08 & 68855,00 & 0,103 \\
\hline 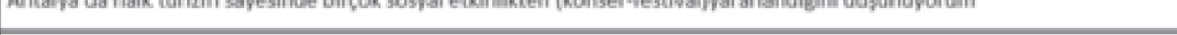 & Bayan & 176 & 221,73 & 39025,00 & \\
\hline 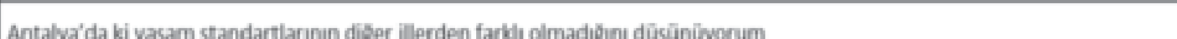 & Bay & 288 & 235,72 & 67888,00 & 0,154 \\
\hline Antalva da ki yagam standartianinin diger ilierden fanki oimadigini duģunoworum & Bayan & 176 & 227,23 & 39992,00 & \\
\hline 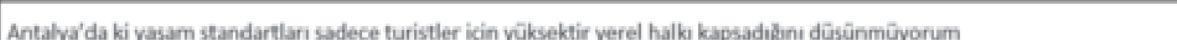 & Bay & 288 & 229,72 & 66160,50 & 0,49 \\
\hline 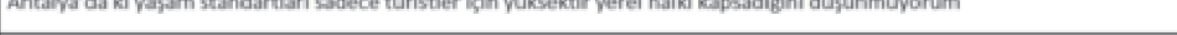 & Bayan & 176 & 237,04 & 41719,50 & \\
\hline 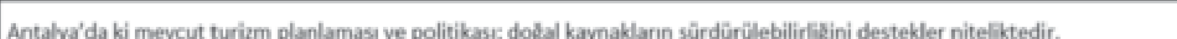 & Bay & 288 & 234,79 & 67619,00 & 0,543 \\
\hline & Bayan & 176 & 228,76 & 40261,00 & \\
\hline 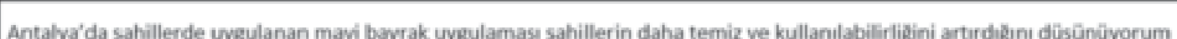 & Bay & 288 & 238,36 & 68649,00 & 0,626 \\
\hline 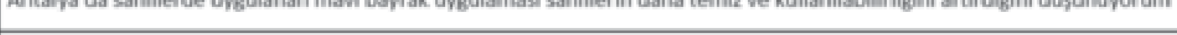 & Baran & 176 & 222,90 & 39231,00 & \\
\hline 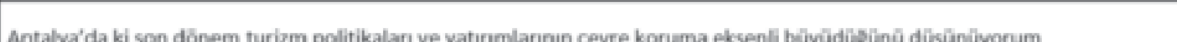 & Bay & 288 & 228,14 & 65705,50 & 0,687 \\
\hline 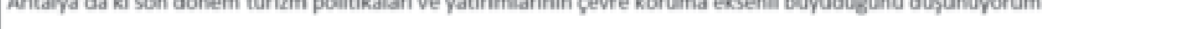 & Buyan & 176 & 239,63 & 42174,50 & \\
\hline
\end{tabular}

\section{Sonuç}

Ekonomiye katkısı, istihdam alanları oluşturması, kırsal kalkınmaya etkisi, diğer sektörlerin gelişimine destek olması ve sosyo-kültürel etkileşimi artırmasından dolayı turizm; Türkiye'nin en önemli ve en hızlı gelişen hizmet sektörlerinden birisidir. Türkiye'de 1980 'li yıllardan itibaren gelişme gösteren turizm hareketliliği, özellikle 2000'li yıllardan sonra uluslararası boyut kazanmış ve Türkiye dünya turizminin en önemli destinasyonlardan birisi haline gelmiştir. Türkiye turizminin bu gelişiminde Antalya ilinin katkısı büyüktür. Antalya ilinin turizmi son yıllarda hızlı bir şekilde gelişmektedir. Bu hızlı gelişim ve değişimle birlikte bu bölgede bulunan yerel halk ve diğer sektörler bu durumdan ciddi olarak etkilenmektedir. İlin turizminin daha sağlıklı gelişiminde bu etkilerin araştrrılmasının önemi büyüktür. Antalya'da turizmin sürdürülebilirliği ve daha sağlıklı gelişmesi açısından, turizmin en önemli paydaşlarından olan yerel halkın görüşlerinin alınması gerekir. Çünkü bölgedeki olumlu ya da olumsuz turizm gelişiminden en fazla etkilenecek olan kesim, bölgede yaşayan yerel halktır. Yerel halka rağmen gerçekleştirilen turizm planlamalarının ve yatırımların, dünyanın birçok bölgesinde olduğu gibi Antalya'da da, turizmin sağlıklı gelişimini ve geleceğini olumsuz etkileyecektir. Bundan dolayı çalışmada, Antalya'nın merkez ilçelerinde yaşayan yerel halka Antalya'nın turizm gelişimi, turizmin etkileri ve sürdürü- lebilirliği konusundaki algılarını belirlemek amacıyla anket uygulaması yapılmıştır.

Ankete katilan bireylerin "Antalya'ya daha fazla turistin gelmesini istiyorum" ifadesine çok yüksek katılım gösterdikleri görülmüştür. Bu durum, ankete katllan bireylerin, Antalya'daki turizmin gelişimine verdikleri önemi göstermesi açısından önemlidir. Ankete göre Antalya merkez ilçelerinde yaşayan yerel halkın, Antalya'nın turizm gelişiminden memnun olduğu ve turizmin daha fazla gelişmesi için yabancı ve nitelikli turistin gelmesi yönünde yaygın kanaate sahip olduğu görülmektedir.

Yapılan analiz sonuçlarına bakıldığında, ankete katılan bireylerin cinsiyetleri ile, bireylerin Antalya turizmine yönelik değerlendirmelerini içeren ifadelere verdikleri cevapların dağılımları arasında istatistiksel olarak anlamlı farklııı̆ın olmadığı ortaya çıkarken, yaş gruplarına ilişkin sonuçlara bakıldığında ise, ankette yer alan maddelerin tümünde olmasa da bazı maddelerde anlamlı farkın olduğu görülmektedir.

Ankete göre, genelde yerel halkın Antalya'da turizmin gelişimine olumlu yönde baktığı anlaşılmaktadır. Ankete katılan yerel halkın; Antalya'ya daha fazla turist gelmesi, gelen turistlerin nitelikli olması, yerli turist yerine yabancı turistin gelmesi, Antalya'ya yapılacak turizm yatırımlarının halkın yaşam standardını artıracağı, turizm sayesinde Antalya'da yaşayan halkın birçok sosyal aktiviteden faydalandığı şeklinde olumlu yaklaştı̆ı 
görülmektedir. Bununla birlikte yerel halkın Antalya'daki turizm gelişimi konusunda bazı çekincelerinin de olduğu anlaşılmaktadır. Ankete katılan bireylerin verdiği cevaplara göre; turizmin halkın yaşam standartlarını artırmasının yanında, turizmdeki planlama ve politikaların, doğal kaynaklardaki sürdürübilirliği destekler nitelikte olmadığı, Antalya'ya gelen yerli turistlerin yeterince bilinçli olmadığı, Antalya'daki kontrolsüz turizm büyümesinin birtakım çevre problemlerine ve şehirde görüntü kir- liliğine sebep olduğu, ildeki turizmin gelişimi ile birlikte fiyatların artthğı sonucu ortaya çıkmaktadır. Sonuç olarak, Antalya turizminin daha sağlıklı, sürdürülebilir ve nitelikli gelişiminin sağlanabilmesi için, yerel halkın görüşünün alınması, beklentilerinin karşılanması, önerilerinin dikkate alınması, olumlu gördüğü yönlerin daha fazla geliştirilmesi ve turizmin olumsuz gelişimi konusundaki tereddütlerinin de giderilmesi gerekmektedir.

Tablo 10. Ankete katılanların yaş guruplarına göre Antalya'da turizme yönelik tutumlarına ilişkin ifadelere katılım ortalamaları Kruskal-Wallis Testi sonuçları. Table 10. The attitudes of the survey participants towards tourism in the province of Antalya by age groups.

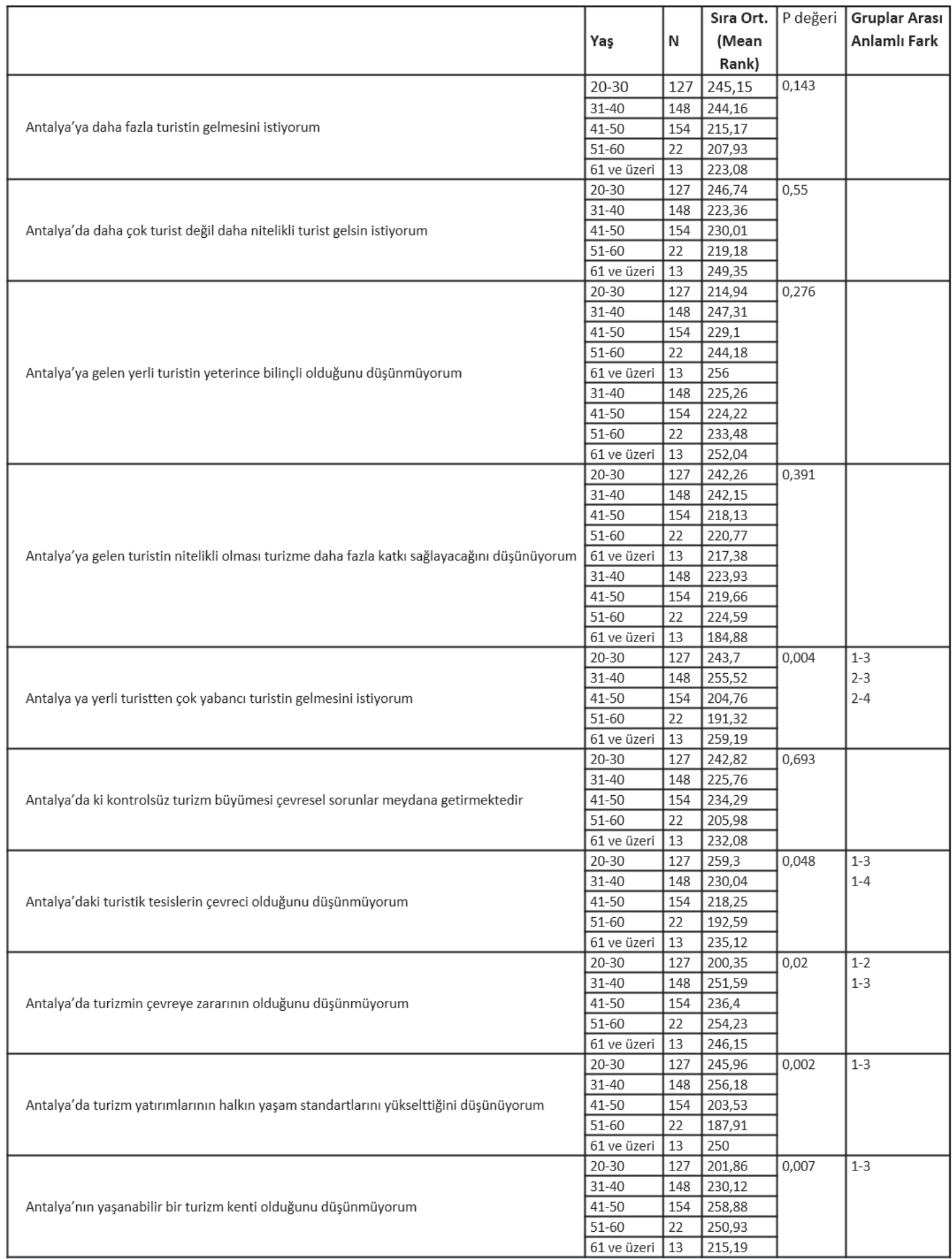


Tablo 10 devamı.

\begin{tabular}{|c|c|c|c|c|c|}
\hline \multirow{5}{*}{ Antalya'da turizmin daha fazla gelişmesini istemiyorum } & $20-30$ & 127 & 188,87 & \multirow[t]{5}{*}{0,78} & \\
\hline & $31-40$ & 148 & 241,51 & & \\
\hline & $41-50$ & 154 & 255,74 & & \\
\hline & $51-60$ & 22 & 265,59 & & \\
\hline & 61 ve üzeri & 13 & 224,96 & & \\
\hline \multirow{5}{*}{ Antalya'da turizmin gelişmesiyle hayat standartlarının pahalılaştığını düşünüyorum } & $20-30$ & 127 & 245,52 & \multirow[t]{5}{*}{0,527} & \\
\hline & $31-40$ & 148 & 236,45 & & \\
\hline & $41-50$ & 154 & 222,11 & & \\
\hline & $51-60$ & 22 & 212,75 & & \\
\hline & 61 ve üzeri & 13 & 216,81 & & \\
\hline \multirow{5}{*}{$\begin{array}{l}\text { Antalya'daki turizm sayesinde arazi, konut, mal ve hizmet fiyatları artışa uğradığını } \\
\text { düşünüyorum }\end{array}$} & $20-30$ & 127 & 240,12 & \multirow[t]{5}{*}{0,395} & \\
\hline & $31-40$ & 148 & 238,52 & & \\
\hline & $41-50$ & 154 & 218,7 & & \\
\hline & $51-60$ & 22 & 221,39 & & \\
\hline & 61 ve üzeri & 13 & 271,85 & & \\
\hline \multirow{5}{*}{$\begin{array}{l}\text { Antalya'da halk turizm sayesinde birçok sosyal etkinlikten (konser-festival)yararlandığını } \\
\text { düşünüyorum }\end{array}$} & $20-30$ & 127 & 255,6 & \multirow[t]{5}{*}{0,011} & \multirow[t]{5}{*}{$1-3$} \\
\hline & $31-40$ & 148 & 242,39 & & \\
\hline & 41-50 & 154 & 207,59 & & \\
\hline & $51-60$ & 22 & 196,73 & & \\
\hline & 61 ve üzeri & 13 & 249,81 & & \\
\hline \multirow{5}{*}{ Antalya'da ki yaşam standartlarının diğer illerden farklı olmadığını düşünüyorum } & $20-30$ & 127 & 235,17 & \multirow[t]{5}{*}{0,949} & \\
\hline & $31-40$ & 148 & 232,13 & & \\
\hline & $41-50$ & 154 & 234,52 & & \\
\hline & $51-60$ & 22 & 217,64 & & \\
\hline & 61 ve üzeri & 13 & 211,92 & & \\
\hline \multirow{5}{*}{$\begin{array}{l}\text { Antalya'da ki yaşam standartları sadece turistler için yüksektir yerel halkı kapsadığını } \\
\text { düşünmüyorum }\end{array}$} & $20-30$ & 127 & 219,22 & \multirow[t]{5}{*}{0,108} & \\
\hline & $31-40$ & 148 & 255,14 & & \\
\hline & $41-50$ & 154 & 222,44 & & \\
\hline & $51-60$ & 22 & 239,16 & & \\
\hline & 61 ve üzeri & 13 & 212,35 & & \\
\hline \multirow{5}{*}{$\begin{array}{l}\text { Antalya'da ki mevcut turizm planlaması ve politikası; doğal kaynakların sürdürülebilirliğini } \\
\text { destekler niteliktedir. }\end{array}$} & $20-30$ & 127 & 245,42 & \multirow[t]{5}{*}{0,098} & \\
\hline & $31-40$ & 148 & 245,57 & & \\
\hline & $41-50$ & 154 & 211,45 & & \\
\hline & $51-60$ & 22 & 207,91 & & \\
\hline & 61 ve üzeri & 13 & 248,38 & & \\
\hline \multirow{5}{*}{$\begin{array}{l}\text { Antalya'da sahillerde uygulanan mavi bayrak uygulaması sahillerin daha temiz ve } \\
\text { kullanılabilirliğini artırdığını düşünüyorum }\end{array}$} & $20-30$ & 127 & 237,44 & \multirow[t]{5}{*}{0,691} & \\
\hline & $31-40$ & 148 & 238,12 & & \\
\hline & $41-50$ & 154 & 220,14 & & \\
\hline & $51-60$ & 22 & 246,34 & & \\
\hline & 61 ve üzeri & 13 & 243,23 & & \\
\hline \multirow{5}{*}{$\begin{array}{l}\text { Antalya'da ki son dönem turizm politikaları ve yatıımlarının çevre koruma eksenli } \\
\text { büyüdüğünü düşünüyorum }\end{array}$} & $20-30$ & 127 & 214,15 & \multirow[t]{5}{*}{0,025} & \multirow{5}{*}{$\begin{array}{l}3-1 \\
3-5\end{array}$} \\
\hline & $31-40$ & 148 & 235,23 & & \\
\hline & \begin{tabular}{|l|}
$41-50$ \\
\end{tabular} & 154 & 252,72 & & \\
\hline & $51-60$ & 22 & 224,36 & & \\
\hline & 61 ve üzeri & 13 & 154,96 & & \\
\hline
\end{tabular}

\section{Kaynakça}

Andereck, K. L., Valentine, K. M., Knopf, R. C. ve Vogt, C. A. (2005). "Residents' Perceptions of Communit y Tourism Impacts", Annals of Tourism Research, 32(4), 1056-1076.

Ap, J. (1992). "Residents' Perceptions on Tourism Impacts", Annals of Tourism Research, 19(4), 67.

Avcıkurt, C. (2003). "Turizm Sosyolojisi: Turist-Yerel Halk Etkileşimi", Detay Yayınları, Ankara, 2003.

Baş, T. (2010). "Anket", Seçkin Yayıncılık, Antalya.

Baykan, E. (2007). "Turizmin Yerel Kültür Üzerindeki Etkilerinin Yöre Halkı Tarafindan Algılanması", Gazi Üniversitesi Eğitim Bilimleri Enstitüsü Turizm İşletmeciliği Eğitimi Ana Bilim Dalı, Master Tezi, Ankara.

Besculides, A., Lee M. E. ve Mccormick P. J. (2002). "Residents' Perceptions of the Cultural Benefit s of Tourism", Annals of Tourism Research, 29(2), 303-319.

Bestard, A. B. ve Nadal, J. R. (2007). "Modelling Environmental Attitudes Toward Tourism". Tourism Management, 28, 688-695.

Bramwell, B. ve Lane, B. (1993). "Sustainable Tourism: An Evolving Global Approach", Journal of Sustainable Tourism, 1(1), 1-5.

Büyüköztürk, Ş. (2013). "Sosyal Bilimler İçin Veri Analizi El Kitabı", Pegem Akademi, Ankara.

Byrd, E. T., Bosley, H. E. ve Dronberger, M. G. (2009). “Comparisons Of Stakeholder Perceptions Of Tourism İmpacts in Rural Eastern
North Carolina". Tourism Management, 30, 693-703.

Doğanay, H. ve Zaman, S. (2013). “Türkiye Turizm Coğrafyası”, Pegem Akademi, Erzurum.

Dyer, P, Gürsoy, D., Sharma, B. ve Carter, J. (2007). "Structural Modeling of Resident Perceptions of Tourism and Associated Development on the Sunshine Coast Australia", Tourism Management, 28, 409-422.

Emekli, G. (2001). “Bergama'nın Turizm Coğrafyası ve Turizmin SosyoEkonomik Etkileri”. Bergama Belediyesi Kültür Yayınları, İzmir.

Gunn , C. A. (1988). "Tourism Planning", Second Edition, Taylor \& Francis, New York.

Gürsoy, D. ve Rutherford D. G. (2004). "Host Attitudes Toward Tourism An Improved Structural Model", Annals of Tourism Research, 31(3), 495-516.

Güneş, N. (2014). "Yerel Halkın Turizm Algısı Ve Turizme Katılımı: Antalya Konyaaltt Ve Kepez illçesi Örneği", Akdeniz Üniversitesi Sosyal Bilimler Enstitüsü, Basılmamış Yüksek Lisans Tezi.

Harrill, R. (2004). "Resident Attitudes toward Tourism Development: A literature Review with Implications for Tourism Planning", Journal of Planning Literature, 18(3), 251-266.

Inskeep, E. (1991). "Tourism Planning: An Integrated and Sustainable Development Approach", Van Nostrand Reinhold, New York.

Içöz, O. ve Kozak, M. (2002). "Turizm Ekonomisi", Turhan Kitabevi, Ankara, 2002.

Jurowski, C., Uysal, M. ve Williams, D. R. (1997). "A Theoretical Analysis of Host Communit y Resident React ions to Tourism", Journal 
of Travel Research, 36(2), 3-11.

Kervankıran, İ. (2013). "Afyonkarahisar İlinin Sürdürülebilir Turizm Açısından Değerlendirilmesi", Kocatepe Akademi Yayınları.

Latkova, P. (2008). "An Examinitaion of Factors Predicting Residents Support for Tourism Development", PhD Thesis, Michigan State University, USA.

Mansuroğlu, S. (2006). "Turizm Gelişmelerine Yerel Halkın YaklaşımIarının Belirlenmesi: Akseki/Antalya Örneği”, Akdeniz Üniv. Ziraat Fakültesi Dergisi, Sayı:19, Antalya.

Mcıntyre, G., Hetherıngton, A. ve Inskeep, E. (1993). "Sustainable Tourism Development: Guide for Local Planners", World Tourism Organization, Madrid, Spain.

Nicholas, L. N., Thapa, B. ve Ko Y. J. (2009). “Residents' Perspectives of a World Heritage Site The Pitons Management Area", St. Lucia. Annals of Tourism Research, 36(3), 390-412.

Ko, D-W., ve Stewart W.P. (2002). "A Structural Equation Model of Resident's Attitudes for Tourism Development", Tourism Management, 23, 521-530.

Kozak, M. (2014). "Sürdürülebilir Turizm: Kavramlar-Uygulamalar", Detay Yayıncılık, Ankara.

Özgüç, N. (2007). "Turizm Coğrafyası”, Çantay Kitabevi, İstanbul.

Sekhar, N. U. (2003). “Local People's Attitudes Towards Conservation And Wildlife Tourism Around Sariska Tiger Reserve", Journal of Environmental Management 69, India.

Soykan, F. (2004). "Kırsal Alanların Turizm Potansiyelinin Saptanması ve Şirince Köyü’ne (İzmir) Uygulanması”, Ege Üniversitesi Basımevi, İzmir.

Swarbrooke, J. (1999). "Sustainable Tourism Management". CABI Publishing, United Kingdom.

Teye, V., Sönmez, S. F. ve Sirakaya, E. (2002). "Residents' Attitudes Towards Tourism Development", Annals of Tourism Research, 29(3), 668-688.

Varnacı Uzun, F. ve Somuncu M. (2011). “Kültürel Peyzajın Korunması ve Turizm İlişkisi Bağlamında Yerel Halkın Görüşleri: Ihlara Vadisi Örneği", Ankara Üniversitesi Çevrebilimleri Dergisi, 3(2), 21-36.

Yazıcıoğlu, Y. ve Erdoğan, S. (2004). "Spss Uygulamalı Bilimsel Araştırma Yöntemleri", Detay Yayıncılık, Ankara.

Yeşiltaş, M. ve Demirçivi, B. M. (2010). “İ̧̧ Görenlerin Yıldırma Eylemlerine Maruz Kalma Durumları Üzerine Bir Araştırma: Antalya Örneği”, Anatolia: Turizm Araştırmaları Dergisi, 21(2), 199-217.

Yoon, Y., Gürsoy, D. ve Chen, J. S. (2001). "Validating A Tourism Development Theory With Structural Equation Modelling", Tourism Management, 22, 363-372.

Yoon, Y. (2002). "Development of a Structural Model for Tourism Destination Competitiveness from Stakeholders' Perspectives". Doctor of Philosophy. Faculty of the Virginia Polytechnic Institute and State University.

Zaman, S. (2007). "Fonksiyonel Değişim Sürecinde Antalya Beydağları Yaylaları", Atatürk Üniversitesi Yayınları, Eser Ofset Matbaacılık, Erzurum.

Internet Adresleri

http://www.turizm.gov.tr./turizm istatistikleri, Erişim Tarihi: 14.04.2015.

http://www.tuik.gov.tr./turizm istatistikleri, Erişim Tarihi: 14.04.2015. 
